\title{
The Prior Question: What Do We Need State Citizenship for?
}

\author{
David Owen
}

In his kick-off contribution, Costica Dumbrava offers a threefold critique of ius sanguinis as a norm of citizenship acquisition. In reflecting on this critique, I share the scepticism expressed by Rainer Bauböck, Jannis Panagioditis, Scott Titshaw and Kristin Collins. In particular I would note, along the lines of Titshaw's Indian family example, that the abolition of ius sanguinis would have led in my own family context to four siblings, of whom I am one, being split among three different nationalities: Nigerian, British and Malaysian). However rather than address Dumbrava's critique head on, I want to suggest that the kind of critique of ius sanguinis that he offers - and the same point would apply to the critique or defence of any of the classic membership rules taken singly as free-standing norms - gets things moving askew from the start. To see this, one needs to take a step back and situate this debate within a slightly different context. When asking what citizenship rules we ought to endorse or reject, we ought to begin with a prior question: 'what do we need state citizenship rules for?'

In a world of plural autonomous states, there are two basic functions that such rules are to play:

1. to ensure that each and every human being is a citizen of a state and hence that everyone has, at least formally, equal standing in a global society organised as a system of states;

2. to allocate persons to states in ways that best serve the common interest, that is, where this allocation supports protection of the fundamental interests of individuals, the realization of the common good within states and the conditions of cooperation between states.

A plausible response to these requirements is a general principle that Ayelet Shachar calls 'ius nexi' which highlights the importance of a genuine connection between persons and the state of which they are citizens. ${ }^{1}$ The notion

\footnotetext{
1 Shachar, A. (2009), The Birthright Lottery: Citizenship and Global Inequality. Cambridge: Harvard University Press. 
of 'genuine connection' can be glossed in terms of Bauböck's 'stakeholder' view which proposes that those and only those individuals have a claim to membership of a polity whose individual autonomy and wellbeing is linked to the collective self-government and flourishing of that polity. ${ }^{2}$ It seems to me that we should see ius soli, ius sanguinis and ius domicilii under the general principle of ius nexi as denoting different routes through which a genuine connection is presumptively established: through parental citizenship, through place of birth and through residence.

Seeing each of these rules under this more general principle, rather than seeing each as a single free-standing norm, makes clear two points that are salient to this discussion. First, that in adopting any of these rules we are not reifying 'blood' or 'territory' or 'residence'. We regard them instead simply as acknowledgments of the diverse ways in which ius nexi may be given expression - and we need each of them if we are to do justice to the relations of persons to states. Second, that each of the ius soli, ius sanguinis and ius domicilii rules should be qualified by the general principle of ius nexi that they serve. So, for example, an unlimited ius sanguinis rule or a ius soli rule that included a child born to visiting tourists or a ius domicilii rule that granted citizenship after three months residence would be incompatible with the overarching ius nexi principle.

Still it would be in line with Dumbrava's argument for him to object that the 'birthright' rules of ius soli and ius sanguinis can only operate on the basis of the general presumption that parental citizenship and place of birth establish a genuine connection, so why not wait until the children reach their majority? Here I concur with the view advanced by Bauböck that the adequate protection of children's rights implies that 'children need not only human rights, they also need their parent's citizenship'. Titshaw's example of the serially mobile Indian family and my own peripatetic family history suffice to make this point. Contra Harder, I don't think that 'birthright' rules disguise the political character of membership norms, rather they acknowledge important interests of children, parents and states. Harder's stress on the relationship of those entitled to citizenship of a given state and those not so entitled doesn't provide reasons to drop either ius soli or ius sanguinis, what it does is provide reasons for relatively generous ius domicilii rules, of

2 Bauböck, R. (2015), 'Morphing the Demos into the Right Shape. Normative Principles for Enfranchising Resident Aliens and Expatriate Citizens',

Democratization 22 (5): 820-839, https://doi.org/10.1080/13510347.2014. 988146. 
rights to dual/plural nationality and of a more equitable distribution of transnational mobility rights.

And perhaps there may be a clue here to an unstated background commitment of Dumbrava's critique. If we ask under what, if any, circumstances in a world of plural states, it could make sense to abolish ius sanguinis rules, then I think that the only answer that has any plausibility is a world of open borders characterised by rapid access to citizenship through ius domicilii rules. It may even be plausible that the abolition of ius sanguinis rules would generate political support for more open borders given the problems liable to be posed for sustaining the human right to a family life after the removal of such rules. Whether this is a prudent way of seeking to realise such a world and whether such a world is desirable are, of course, further questions.

Open Access This chapter is licensed under the terms of the Creative Commons Attribution 4.0 International License (http://creativecommons.org/licenses/by/4.0/), which permits use, sharing, adaptation, distribution and reproduction in any medium or format, as long as you give appropriate credit to the original author(s) and the source, provide a link to the Creative Commons license and indicate if changes were made.

The images or other third party material in this chapter are included in the chapter's Creative Commons license, unless indicated otherwise in a credit line to the material. If material is not included in the chapter's Creative Commons license and your intended use is not permitted by statutory regulation or exceeds the permitted use, you will need to obtain permission directly from the copyright holder.

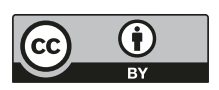

